\title{
NUMERICAL ALGORITHM FOR FINDING OPTIMAL INITIAL CONCENTRATIONS OF CHEMICAL REACTIONS
}

\author{
Svetlana Mustafina ${ }^{1 *}$, ANdrey ANTIPIN ${ }^{1}$, Evgenia ANTIPINA ${ }^{1}$, \\ ElenA ODINOKOVA ${ }^{2}$, LARISA TUCHKINA ${ }^{2}$, KONSTANTIN KOLYAZOV ${ }^{2}$, \\ AND SOFIA MUSTAFINA ${ }^{1}$ \\ ${ }^{I}$ Dept. Mathematics and Information Technology, Bashkir State University, Ufa, Russia \\ ${ }^{2}$ Dept. Information Technology and Management Systems, Moscow State University of \\ Technologies and Management, Moscow, Russia. \\ *Corresponding author: Mustafina_SA@mail.ru
}

(Received: $16^{\text {th }}$ June 2019; Accepted: 19 $9^{\text {th }}$ October 2019; Published on-line: $20^{\text {th }}$ January 2020)

\begin{abstract}
This article is devoted to the problem of developing methods for mathematical modelling in the sphere of optimal planning in a chemical experiment. In the article, the problem of finding the optimal ratio for initial concentrations of substances is formulated in general terms and an algorithm for solving this problem is constructed basing on the method of artificial immune systems. The developed algorithm for finding the optimal initial concentrations of substances allows solving the problem of experiment planning in chemistry at the computational experiment stage. In this case, the solution of the optimization problem found with its help does not depend on the choice of the initial approximation. The algorithm was tested for the industrially meaningful process of benzilidenebenzilamine synthesis for which the optimum values of the initial concentrations were calculated in order to obtain maximum yield of the reaction product.
\end{abstract}

\begin{abstract}
ABSTRAK: Artikel ini ditujukan untuk masalah mengembangkan kaedah pemodelan matematik dalam bidang perancangan optimum dalam percubaan kimia. Dalam artikel itu, masalah mencari nisbah optimum untuk konsentrasi awal bahan digubal secara umum dan algoritma untuk menyelesaikan masalah ini dibina berdasarkan kaedah sistem imun buatan. Algoritma yang dibangunkan untuk mencari kandungan konsentrasi awal yang optimum membolehkan menyelesaikan masalah perancangan percubaan dalam kimia pada peringkat percubaan pengkomputeran. Dalam kes ini, penyelesaian masalah pengoptimuman yang didapati dengan bantuannya tidak bergantung pada pilihan permulaan awal. Algoritma ini telah diuji untuk proses sintesis benzilidenebenzilamin yang bermakna industri yang mana nilai-nilai optimum kepekatan awal dikira untuk mendapatkan hasil maksimum produk reaksin.
\end{abstract}

KEYWORDS: chemical kinetics; artificial immune systems; initial concentration

\section{INTRODUCTION}

The solution to many problems in chemistry and chemical technology is associated with complex and expensive experiments. In the study of the chemical process at the computational experiment stage, it is advisable to identify its main regularities because of the complexity of the initial raw materials' compositions and the low content of valuable components in them. In this regard, the actual task is to develop methods for optimal planning of the experiment, which allow saving time and material resources for conducting a full-scale experiment. 
The development of computer technology and information technology allows the use of mathematical methods in the planning of the chemical experiments. The methods of mathematical modelling allow the determination of optimal concentrations of reagents to obtain the best yield of the final product and significantly reduce the cost of substance synthesis.

The calculation of the initial concentrations of the reactants in a chemical reaction is made by searching for an extremum of the function for calculating the dynamics of the substance concentrations during the chemical experiment. The significant drawbacks of most numerical methods for finding the extremum of functions are the difficulties in achieving convergence of the process, which depends on the choice of the initial approximation.

Currently, metaheuristic optimization methods are widely used, which make it possible to efficiently find a global optimum in a reasonable time [1-3]. Their important feature is the ability to overcome the local extremum point of the target function in the search process. Therefore, they allow finding better solutions in comparison with classical heuristics [4-7].

Among the metaheuristic algorithms, the method of artificial immune systems is distinguished. Its advantage is the presence of a memory mechanism. The memory mechanism makes it possible to use information about previously found best solutions, thereby increasing the efficiency of global search. An important feature of the method of artificial immune systems is the independence of the optimization problem solution from the initial approximation [8-10].

\section{FORMULATION OF THE PROBLEM}

Let us formulate in general terms the problem of finding the optimal ratio for initial concentrations of substances. A mathematical model for the dynamics of substance concentrations is a system of ordinary differential equations

$$
\frac{d x}{d t}=f(t, x(t), T)
$$

with initial conditions

$$
x_{i}(0)=x_{i}^{0}, \quad i=\overline{1, n},
$$

where $x(t)=\left(x_{1}(t), x_{2}(t), \ldots \quad\right.$ is the vector of the concentrations of the reacting substances, $f(t, x(t), T)$ is continuous together with their partial derivatives of the function, $t \in\left[0, t_{2}\right]$ is the time of reaction, and $T$ is the reaction temperature [11].

At the initial moment of time, substances are interconnected by some ratio:

$$
x_{1}(0): \ldots
$$

It is required to find the ratio for initial concentrations of substances, which ensures the extremum of optimality criterion

$$
Q(x)=\sum_{i=1}^{n} \lambda_{i} x_{i}\left(t_{2}\right) \rightarrow \text { extr. }
$$

The optimality criterion expresses the maximum yield of the target products or the minimum impurity content depending on the coefficients $\lambda_{i}$ (positive or negative). You 
can also specify some economic criterion, then the coefficients $\lambda_{i}$ are the cost coefficients of the reagents.

\section{THE ALGORITHM FOR THE METHOD OF ARTIFICIAL IMMUNE SYSTEMS TO CALCULATE OPTIMAL INITIAL CONCENTRATIONS OF SUBSTANCES}

The method of artificial immune systems simulates the functioning of a living organism immune system, designed to destroy foreign bodies and improve the fight against them. Consider the main concepts of the method.

An antigen is an alien substance from which the body tries to protect itself with antibodies. An antibody is a substance that recognizes and destroys an antigen [12]. A memory cell is an immune cell that accumulates data about new antibodies that can recognize an antigen. The target function of the optimization problem is called the fitness function $[13,14]$.

As a function of fitness, we used the maximum yield of the target reaction product at the final moment of the reaction. This required the solution of a direct kinetic problem with a given ratio for the initial concentrations of the initial substances, that is, the solution of a system of differential equations (Eq. (1)) with initial conditions (Eq. (2)).

We modified the algorithm to solve the problem of finding the optimal initial concentrations of the components in the reacting mixture. As a population of immune cells, we introduced sets of initial concentrations of substances $x^{j}(0)=\left(x_{1}^{j}(0), x_{2}^{j}(0), \ldots \quad \ldots \quad, j=\overline{1, k}\right.$, where $k$ is the number of immune cells in the population.

To calculate the value of the fitness function $Q(x)$, it is necessary to know the concentration of reagents at the final point in time. To do this, we introduced a block for solving a direct kinetic problem into the algorithm.

The problem of finding the minimum of the target function $Q(x)$ was reduced to the problem of finding the maximum by replacing the sign in front of the function with the opposite one: $Q\left(x^{*}\right)=\min Q(x)=\max [-Q(x)]$. If $Q(x)$ was positive then $Q\left(x^{*}\right)<0$.

We formulated this algorithm.

Step 1. The creation of an initial population for the starting substance concentrations.

Set the number of immune cells in the population $k$, the number of parental cells for the selection $r_{-}$sel, the number of cells in the population with the worst value of the fitness function $n \_b a d$, the maximum number of iterations $i_{-} \max$, the clone operator parameter $n \_c l$, the mutation parameter $m$, the iteration counter num $=0$.

Randomly set the values of $k$ cells of the initial population $x^{j}(0), j=\overline{1, k}$, $0 \leq x^{j}(0)<1$.

Step 2. Calculation of fitness function values.

For sets $x^{j}(0)$ calculate the value of fitness function $Q\left(x^{j}\right)$, by solving a direct kinetic problem for each immune cell. That is, at this step it is necessary to find a numerical solution to the system of differential equations (Eq. (1)) with the initial 
conditions (Eq. (2)) by an explicit or implicit method. The initial conditions of the system (Eq. (2)) are the immune cell.

\section{Step 3. Cloning.}

Select $r$ sel parent cells from the population (a set of antibodies), which correspond to the best values of fitness function $Q(x)$. Generate $n \_c l$ clones for each cell.

\section{Step 4. Mutation.}

For each parent cell generate random numbers $l \in[0,1], \quad h_{1} \in\left[0,1-x_{i}^{j}(0)\right]$, $h_{2} \in\left[0, x_{i}^{j}(0)\right], i=\overline{1, n}$. Perform a mutation of its clones by the rule: if $l>0,5$, then $x_{i}^{s}(0):=x_{i}^{s}(0)+h_{1} \cdot m$, else $x_{i}^{s}(0):=x_{i}^{s}(0)-h_{2} \cdot m$, where $s=\overline{1, n \_c l}, m$ - mutation parameter.

Step 5. Calculation of fitness function values.

For each mutant clone calculate the value of the fitness function by Eq. (4).

Step 6. Selection and transition to a new population.

For each parent cell, find the mutant clone with the lowest value of the fitness function. Compare its value with the value of the fitness function of the parent cell. In the new population, leave the parent cell or replace it with a mutant clone with the best fitness function value.

\section{Step 7. Renewal of a population.}

In the population, find $n_{-} b a d$ cells with the lowest value of fitness function $Q(x)$. Replace these cells with new ones, randomly generated in the interval $[0,1)$, and calculate the value of the fitness function $Q(x)$ for them.

Increase the iteration counter: $n u m=n u m+1$.

Step 8. Checking the conditions for the end of search.

If $n u m<i$ max, then go to step 3, else finish the search and go to step 9.

Step 9. Selection of optimal concentrations of substances from the population.

As a solution to the problem of finding the optimal concentrations of substances, select the cell with the highest fitness function value from the last population.

The developed algorithm was implemented as a software tool in the visual programming environment Delphi.

\section{COMPUTATIONAL EXPERIMENT}

Based on the formulated algorithm, we calculated the optimal ratio of the initial concentrations for the reaction of the benzylidenebenzylamine synthesis in order to obtain the maximum yield of the reaction product. The mechanism of the chemical reaction for the synthesis of benzylidenebenzylamine in the presence of a catalyst $\mathrm{FeCl}_{3} \cdot 6 \mathrm{H}_{2} \mathrm{O}$ is represented by a set of stages [15]: 


$$
\begin{aligned}
& X_{1}+X_{2} \rightarrow X_{3}+X_{4}, \\
& X_{3} \rightarrow X_{5}+X_{6}, \\
& X_{5}+X_{1} \rightarrow X_{7}+X_{8}, \\
& X_{8}+X_{6} \rightarrow X_{9},
\end{aligned}
$$

where $X_{1}$ - benzylamine $\left(C_{7} H_{9} N\right), X_{2}-$ carbon tetrachloride $\left(C_{C l}\right), X_{3}-$ chlorobenzylamine $\left(\mathrm{C}_{7} \mathrm{H}_{8} \mathrm{NCl}\right), \mathrm{X}_{4}-$ chloroform $\left(\mathrm{CHCl}_{3}\right), \mathrm{X}_{5}-1$-phenylmethanimine $\left(\mathrm{C}_{7} \mathrm{H}_{7} \mathrm{~N}\right), \mathrm{X}_{6}$ - hydrogen chloride $(\mathrm{HCl}), \mathrm{X}_{7}$ - benzylidenebenzylamine $\left(\mathrm{C}_{14} \mathrm{H}_{13} \mathrm{~N}\right), \mathrm{X}_{8}-$ ammonium $\left(\mathrm{NH}_{3}\right), \mathrm{X}_{9}$ - ammonium chloride $\left(\mathrm{NH}_{4} \mathrm{Cl}\right)$.

The speed of each stage is determined according to the law of mass action:

$$
\begin{aligned}
& \omega_{1}=k_{1} x_{1} x_{2}, \\
& \omega_{2}=k_{2} x_{3}, \\
& \omega_{3}=k_{3} x_{5} x_{1}, \\
& \omega_{4}=k_{4} x_{8} x_{6},
\end{aligned}
$$

where $x_{i}$ is the concentration of the $i$-th substance $(i=\overline{1,9})$ (mole fraction), $k_{j}$ is the rate constant of the $j$-th reaction stage $(j=\overline{1,4})$, calculated according to the Arrhenius equation

$$
k_{j}(T)=k_{0 j} \cdot \exp \left(-\frac{E_{j}}{R T}\right),
$$

where $E_{j}$ is the energy of activation of the $\mathrm{j}$-th stage $(\mathrm{kJ} / \mathrm{mol}), T$ is the reaction temperature $(\mathrm{K})$, and $R$ is the universal gas constant $(8,31 \mathrm{~J} /(\mathrm{mol} \cdot \mathrm{K}))$.

The matrix of stoichiometric coefficients of substances $\left(\gamma_{i j}\right)(i=\overline{1,4}, j=\overline{1,9})$ is given in Table 1.

Table 1: Matrix of stoichiometric coefficients of the reaction of synthesis of benzylidenebenzylamine

\begin{tabular}{ccccc}
\hline & $\boldsymbol{\omega}_{\mathbf{1}}$ & $\boldsymbol{\omega}_{2}$ & $\boldsymbol{\omega}_{3}$ & $\boldsymbol{\omega}_{4}$ \\
\hline$X_{1}$ & $\mathbf{- 1}$ & $\mathbf{0}$ & $\mathbf{- 1}$ & $\mathbf{0}$ \\
$X_{2}$ & $\mathbf{- 1}$ & $\mathbf{0}$ & $\mathbf{0}$ & $\mathbf{0}$ \\
$X_{3}$ & $\mathbf{1}$ & $\mathbf{- 1}$ & $\mathbf{0}$ & $\mathbf{0}$ \\
$X_{4}$ & $\mathbf{1}$ & $\mathbf{0}$ & $\mathbf{0}$ & $\mathbf{0}$ \\
$X_{5}$ & $\mathbf{0}$ & $\mathbf{1}$ & $\mathbf{- 1}$ & $\mathbf{0}$ \\
$X_{6}$ & $\mathbf{0}$ & $\mathbf{1}$ & $\mathbf{0}$ & $\mathbf{- 1}$ \\
$X_{7}$ & $\mathbf{0}$ & $\mathbf{0}$ & $\mathbf{1}$ & $\mathbf{0}$ \\
$X_{8}$ & $\mathbf{0}$ & $\mathbf{0}$ & $\mathbf{1}$ & $\mathbf{- 1}$ \\
$X_{9}$ & $\mathbf{0}$ & $\mathbf{0}$ & $\mathbf{0}$ & $\mathbf{1}$ \\
$\delta$ & $\mathbf{0}$ & $\mathbf{1}$ & $\mathbf{0}$ & $\mathbf{- 1}$ \\
\hline
\end{tabular}

Since there are nonzero elements among the elements of the last line $\delta$, the reaction proceeds with a change in the reaction volume $[16,17]$. Then the kinetic model of the reaction is a system of differential equations: 


$$
\left\{\begin{array}{l}
\frac{d x_{i}}{d t}=\frac{F_{i}(x, T)-x_{i} \cdot F_{n}(x, T)}{N}, i=\overline{1,9}, \\
\frac{d N}{d t}=F_{n}(x, T)
\end{array}\right.
$$

with initial conditions:

$$
x_{i}(0)=x_{i}^{0}, \quad i=\overline{1,9}, \quad N(0)=1,
$$

where $N$ is the variable reaction volume, $F_{i}=\sum_{j=1}^{4} \gamma_{i j} W_{j}, \quad i=\overline{1,9}, \quad F_{n}=\sum_{j=1}^{4} W_{j} \sum_{i=1}^{9} \gamma_{i j}$, $W_{j}=\frac{\omega_{j}}{C_{0}}$ is the values of rate of reaction stages $(j=\overline{1,4})\left(\mathrm{h}^{-1}\right)$, and $C_{0}$ is the initial total concentration of substances $(\mathrm{mol} / \mathrm{l})$.

The functions $F_{n}(x, T), F_{i}(x, T)(i=\overline{1,9})$ have the form:

$$
\begin{aligned}
& F_{1}(x, T)=-W_{1}(x, T)-W_{3}(x, T), \\
& F_{2}(x, T)=-W_{1}(x, T), \\
& F_{3}(x, T)=W_{1}(x, T)-W_{2}(x, T), \\
& F_{4}(x, T)=W_{1}(x, T), \\
& F_{5}(x, T)=W_{2}(x, T)-W_{3}(x, T), \\
& F_{6}(x, T)=W_{2}(x, T)-W_{4}(x, T), \\
& F_{7}(x, T)=W_{3}(x, T), \\
& F_{8}(x, T)=W_{3}(x, T)-W_{4}(x, T), \\
& F_{9}(x, T)=W_{4}(x, T), \\
& F_{n}(x, T)=W_{2}(x, T)-W_{4}(x, T),
\end{aligned}
$$

The initial substances of the reaction are benzylamine $\left(X_{1}\right)$ and carbon tetrachloride $\left(X_{2}\right)$, the concentrations of which are related by the ratio: $x_{1}(0)+x_{2}(0)=1$.

For other substances $x_{i}(0)=0, i=\overline{3,9}$.

Since the target substance of the reaction scheme is benzylideneaniline $\left(X_{7}\right)$, the optimization problem is formulated as follows: find the ratio for the initial concentrations $x_{1}(0): x_{2}(0)$ of the source substances $X_{1}$ and $X_{2}$, at which at the final time of the reaction the maximum yield of benzylidenebenzylamine $X_{7}$ is reached, i.e. $Q(x)=x_{7}\left(t_{2}\right) \rightarrow \max$.

The solution of this problem was obtained at the temperature $T=23^{\circ} \mathrm{C}$ and the time of the reaction was $t_{2}=4 \mathrm{~h}$. The solution of the system (Eq. (7)) with initial conditions (Eq. (8)) was obtained by the implicit Euler method.

The result of the calculation obtained the optimal ratio for the initial concentrations of the source substances was:

$$
x_{1}(0): x_{2}(0)=0,51: 0,49 \text {. }
$$

The maximum yield of the reaction (benzylideneaniline) was 0,013 mole fractions. 
Figure 1 shows the dynamics of the benzylidenebenzylamine concentration at optimal initial concentrations.

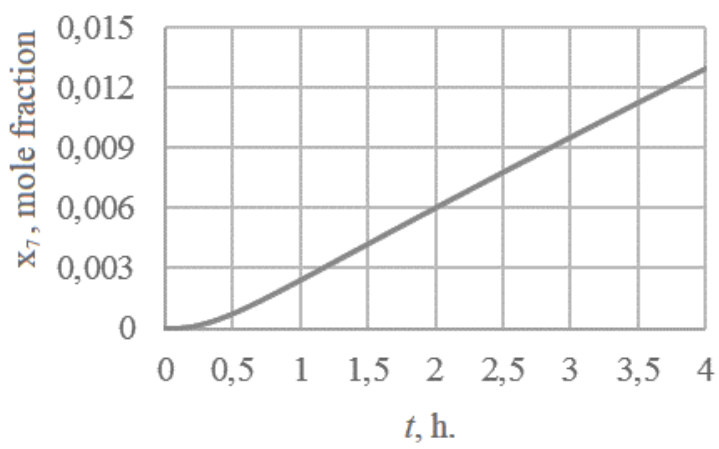

Fig. 1: Dynamics of the optimal concentration of benzylidenebenzylamine.

\section{CONCLUSIONS}

Consider the solution of a direct kinetic problem for the reaction scheme (Eq. (5)) with arbitrary sets for initial concentrations of substances.

According to Table 2, the maximum concentration of benzylidenebenzylamine is observed at a specific ratio of the source substances (Eq. (10)). This confirms the correct operation of the algorithm.

Table 2: Dependence of the concentration of benzylidenebenzylamine $X_{7}$ from the ratio of source substances $X_{1}$ and $X_{2}$

\begin{tabular}{ccc}
\hline $\begin{array}{c}\boldsymbol{x}_{1}, \text { mole } \\
\text { fraction }\end{array}$ & $\begin{array}{l}\boldsymbol{x}_{2} \text {, mole } \\
\text { fraction }\end{array}$ & $\begin{array}{c}\boldsymbol{x}_{7}, \text { mole } \\
\text { fraction }\end{array}$ \\
\hline 0.1 & 0.9 & 0.004 \\
0.2 & 0.8 & 0.008 \\
0.3 & 0.7 & 0.010 \\
0.4 & 0.6 & 0.012 \\
0.51 & 0.49 & 0.013 \\
0.7 & 0.3 & 0.011 \\
0.8 & 0.2 & 0.009 \\
0.9 & 0.1 & 0.005 \\
\hline
\end{tabular}

Thus, the developed algorithm for finding the optimal initial concentrations of the initial substances makes it possible to solve the problem of planning an experiment in chemistry at the stage of a computational experiment. The solution of the optimization problem will be found for any set of values of the initial concentrations of substances, since the work of the artificial immune systems method does not depend on the initial approximation.

\section{ACKNOWLEDGEMENT}

The reported study was funded by RFBR according to the research project No 17-47020068 and project No. 13.5143.2017 / 8.9. 


\section{REFERENCES}

[1] Goldberg D. (1989) Genetic Algorithms in Search, Optimization and Machine Learning. Addison-Wesley, USA.

[2] Holland JN. (1975) Adaptation in Natural and Artificial Systems. Ann Arbor, Michigan: Univ. of Michigan Press.

[3] Stepashina EV. (2014) Optimization the financial performance of enterprise on neural network model. Information Systems and Technologies, 5: 34-42.

[4] Igel C, Hansen N, Roth St. (2007) Covariance matrix adaptation for multi-objective optimization. Evolutionary Computation, 15(1): 1-28.

[5] Mahdavi M. (2007) An improved harmony search algorithm for solving optimization problems. Applied Mathematics and Computation, 188(2): 1567-1579.

[6] Herrera F, Lozano M, Verdegay JL. (1998) Tackling real-coded genetic algorithms: operators and tools for the behavior analysis. Artificial Intelligence Review, 12(4): 265-319.

[7] Lee KS, Geem ZW.(2005) A new meta-heuristic algorithm for continuous engineering optimization: harmony search theory and practice. Computer Methods in Applied Mechanics and Engineering, 194: 3902-3933.

[8] Ishida Y, Hirayama H, Fujita H, Ishiguro A, Mori K. (1998) Immunity-Based SystemsIntelligent Systems by Artificial Immune Systems. Corona Pub. Co., Japan.

[9] Sedova NA, Sedov VA, Bazhenov RI. (2018) Analysis of emergency level at sea using fuzzy logic approaches. Advances in Intelligent Systems and Computing, 658: 314-322.

[10] Antipin AF. (2013) A computer-aided system for designing multidimensional logic controllers with variables representing a set of binary logic arguments. Automation and Remote Control, 74(9): 1573-1581.

[11] Mustafina SA, Vaytiev VA, Stepashina EV. (2014) Search the kinetic parameters of the reduced scheme of A-methylstyrene dimerization reaction. ARPN Journal of Engineering and Applied Sciences, 9(7): 1118-1120.

[12] de Castro L, Timmis J. (2002) An Artificial Immune Network for Multimodal Function Optimization. Proceedings of IEEE Congress on Evolutionary Computation, 1: 669-674.

[13] Panteleev AV, Metlitskaya DV. (2012) Applying of the method of the synthetic immune systems in a problems of searching comditional extremum of the function. Civil Aviation High Technologies, 184: 54-61.

[14] Antipin AF. (2015) Improving response time of real time control systems based on multidimensional interval-logical controllers. Automation and Remote Control, 76(3): 480486.

[15] Stepashina EV, Baitimerova AI, Mustafina SA. (2011) The software package for the computer aided procedure of qualified mechanism of chemical reactions based on DRGEP method. Bashkir chemical journal, 18(3): 112-115.

[16] Vaytiev VA, Stepashina EV, Mustafina SA. (2013) Identification of a mathematical model of the reduced scheme of $\alpha$-methylstyrene dimerization reaction. European Journal of Natural History, 6: 30-32.

[17] Sedov VA, Sedova NA. (2014) Modelling collision avoidance actions in closest approach zones by means of neural networks. Asia-Pacific Journal of Marine Science \& Education, 4(2): 104-111. 